\title{
Study of the static and seismic performance of a geogrid reinforced soil wall as bridge abutment in Concepción
}

Estudio de la respuesta estática y sísmica de un muro de suelo reforzado con geomalla como estribo de puente en Concepción

Fecha de entrega: 17 de enero 2018

Fecha de aceptación: 27 de agosto 2018

\section{Maribell González 1 , Felipe Villalobos², Alejandro Méndez ${ }^{3}$ and Pablo Carrillo $^{3}$}

${ }^{1}$ Departamento Técnico SECPLAN, Municipalidad de Llanquihue, Erardo Werner 450, Llanquihue, Región de Los Lagos, Chile, mgonzalez@1lanquihue.cl

${ }^{2}$ Laboratorio de Geomateriales, Departamento de Ingeniería Civil, Facultad de Ingeniería, Universidad Católica de la Santísima Concepción, Alonso de Ribera 2850, Campus San Andrés, Casilla 297, Concepción, Chile, avillalobos@ucsc.cl (Orcid: 0000-0002-5419-3958)

${ }_{3}^{3}$ EMIN Sistemas Geotécnicos, Félix de Amesti 90, Las Condes, Región Metropolitana, Chile, amendez@emin.cl, pcarrillo@emin.cl

The 27th February 2010 earthquake in central and south of Chile was a very strong test for recently constructed geosynthetics reinforced soil wall solutions as bridge abutments. This 8.8 moment magnitude subduction earthquake caused severe damage to several traditional reinforced concrete walls for bridge abutments. However, no significant damage was found in relatively new geosynthetics reinforced solutions. For that reason, it is important to review the design and construction employed in these projects. To this end, a representative case located close to the epicentre is described and studied. Moreover, information is provided regarding the foundation soils, design and construction sequence of the geosynthetics reinforcement used for bridge abutments. The foundation soils were poor, corresponding mainly to marine and fluvial deposits close to the stream and mouth of the Andalien River. The analysis covers the verification of static and seismic external and internal stability. In addition, global static and seismic analyses are carried out. The methods used for the analyses are limit equilibrium and pseudostatic following recommendations of the FHWA. Results show that the design was adequate to cope with such a strong seismic event in terms of external and internal stability. Nevertheless, it was found that the inclusion of piles prevented a global seismic failure of the geogrid reinforced soil walls as bridge abutment. Final comments and remarks are presented related to design and construction which may explain the favourable performance of geosynthetics reinforced structures under this strong subduction earthquake.

Keywords: geogrid, reinforced soil wall, static and seismic stability, internal and external stability
El terremoto del 27 de febrero 2010 en Chile central y sur fue una prueba muy intensa para las soluciones con muro de suelo reforzado recientemente construidas como estribos de puente. Este terremoto de subducción de magnitud momento 8.8 causó graves daños a varios muros de hormigón armado tradicionales para estribos de puentes. Sin embargo, no se registró mayor daño en soluciones relativamente nuevas y reforzadas con geosintéticos. Por esta razón, es importante revisar el diseño y construcción empleada en estos proyectos. Para este fin, se describe y estudia un caso representativo ubicado próximo al epicentro. Además, se entrega información sobre los suelos de fundación, diseño y secuencia constructiva de los refuerzos de geosintéticos usados en los estribos de puente. Los suelos de fundación eran desfavorables, correspondiendo principalmente a depósitos fluviales y marinos próximos al cauce y desembocadura del río Andalién. El análisis incluye la verificación de la estabilidad estática y sísmica, tanto externa como interna. También se realizan análisis de estabilidad global estática y sísmica. Los métodos usados en los análisis son equilibrio límite y pseudo estático según las recomendaciones de FHWA. Resultados muestran que el diseño fue adecuado para soportar un evento sísmico tan fuerte en términos de estabilidad interna y externa. No obstante, se encontró que la presencia de pilotes prevenía una falla sísmica global del muro de suelo reforzado con geomallas como estribo de puente. Se realizan comentarios y observaciones finales relacionados con el diseño y construcción que podrían explicar la respuesta favorable de las estructuras reforzadas con geosintéticos sometidas a este fuerte terremoto de subducción.

Palabras clave: geomalla, muro de suelo reforzado, estabilidad estática y sísmica, estabilidad interna y externa 


\section{Introduction}

The $27^{\text {th }}$ February 2010 subduction earthquake in Central and South of Chile with a moment magnitude $M_{\mathrm{w}}=8.8$ was a very strong and long movement which affected an important percentage of the national motorway and railway infrastructure (e.g. Buckle et al., 2012; Hube et al., 2010; Ledezma et al., 2012; Verdugo et al., 2010). For instance, in the Romero overpass bridge built in 2001 and located in Paine, $40 \mathrm{~km}$ South of Santiago, structural and geotechnical related damages during this earthquake were reported. Despite the bridge was founded with 1.5 $\mathrm{m}$ diameter and $11 \mathrm{~m}$ up to $30 \mathrm{~m}$ deep piles due to poor subsoil resistance, it suffered significant abutment failure because the concrete retaining structure could not resist the lateral seismic loading (FHWA, 2011). Although the Chada overpass bridge, $10 \mathrm{~km}$ South East from Romero, did not fall down, the abutment was also severely damaged, mainly due to large embankment deformations behind the abutment made with an inclined gravity wall (FHWA, 2011; Hube et al., 2010). No liquefaction was observed in these places.

On the other hand, Ruiz-Tagle and Villalobos (2011a) mention several bridges with abutments made of geogrid reinforced soil walls which withstood without problems the strong $27 \mathrm{~F}$ earthquake, namely, Costanera Norte in Santiago, San Francisco de Mostazal in Rancagua, Bonilla roundabout in Concepción, Las Ballenas in PencoTalcahuano Interportuaria motorway, North access in Chiguayante and Temuco.

The double track skewed railway bridge of San Francisco de Mostazal close to Rancagua built in 2001, has two HDPT uniaxial geogrid reinforced soil walls of $9 \mathrm{~m}$ maximum height with a façade made of modular concrete blocks (Figure 1a). This geogrid reinforced wall did not suffer noticeable displacement or deformation, however the bridge superstructure displaced around 5 to $10 \mathrm{~cm}$ probably due to the angle of skew. Another bridge $1 \mathrm{~km}$ away built using traditional reinforced concrete abutment suffered lateral displacements of around $1 \mathrm{~m}$, despite not be a skewed bridge.

Four geogrid reinforced walls of the Bonilla Bridge in Concepción with $5 \mathrm{~m}$ maximum height are part of a roundabout which is a key point for traffic coming from and going to the North, East and South of the country. This bridge was just being in use some days before the earthquake in February 2010 and with a programmed inauguration in March 2010. A special challenge was to cope with the low bearing capacity and compressibility of the foundation soil close to the Andalién River. To overcome this problem, 2 $\mathrm{m}$ deep of this silty soil was replaced by compacted sand. After the 27F earthquake, vertical displacement not larger than $5 \mathrm{~cm}$ occurred in the geogrid reinforced wall. These settlements caused a long gap to appear in between a row of blocks on the top of the wall. A fine crack of a couple of millimetres also appeared in the ornamental beam above on top of the wall (Figure 1b). However, the Bonilla Bridge did not suffer any damage and could be used without any problem after the earthquake.

In the overpass of Ruta 78 junction in Pajaritos Avenue in the way to Melipilla in Santiago, a $6 \mathrm{~m}$ high curved abutment of geogrid reinforced soil wall was built. The foundation soil was gravel and the fill material used was ignimbrite known locally as Pumacita. This volcanic material is light and therefore very good as fill since applies less lateral earth pressure, and has a relative high shear strength. This project did not suffer any visible damage and no displacement or movement was possible to record despite the curved geometry of the wall (Figure 1c).

There are other similar projects in Chiguayante, Santiago, Talca, San Bernardo, Concepción and Temuco, where geogrid reinforced soil walls were designed also for angles of internal friction of the reinforced fill between $37^{\circ}$ and $42^{\circ}$ and a maximum design acceleration between $0.3 \mathrm{~g}$ and $0.4 \mathrm{~g}$, resulting in almost negligible damage too. The former acceleration is normally applied in projects in the country central valley (Santiago, Rancagua, Talca, etc.) and the latter in coastal areas (Constitución, Concepción, etc.).

There have been similar reported cases in other countries, for example by Tatsuoka et al. (1996, 1998), who were probably the first to report the favourable seismic behaviour of geogrid reinforced soil walls after the 1995 Hyogoken-Nambu earthquake in Kobe, Japan. They reported several damages of different types of retaining walls, where old walls had the most serious damage, whilst gravity walls had low stability against the strong shaking and cantilever reinforced walls had a poor behaviour too. However, a geogrid reinforced soil retaining wall built 
a)

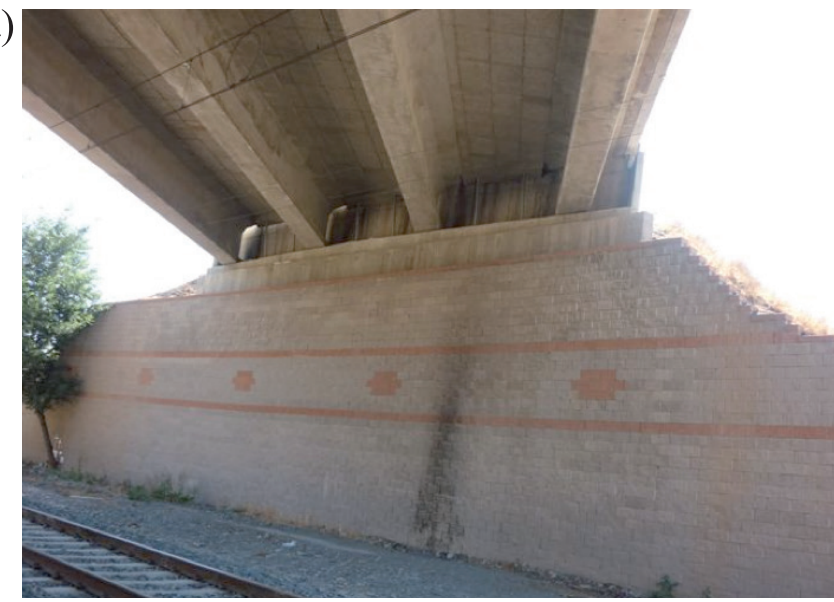

b)

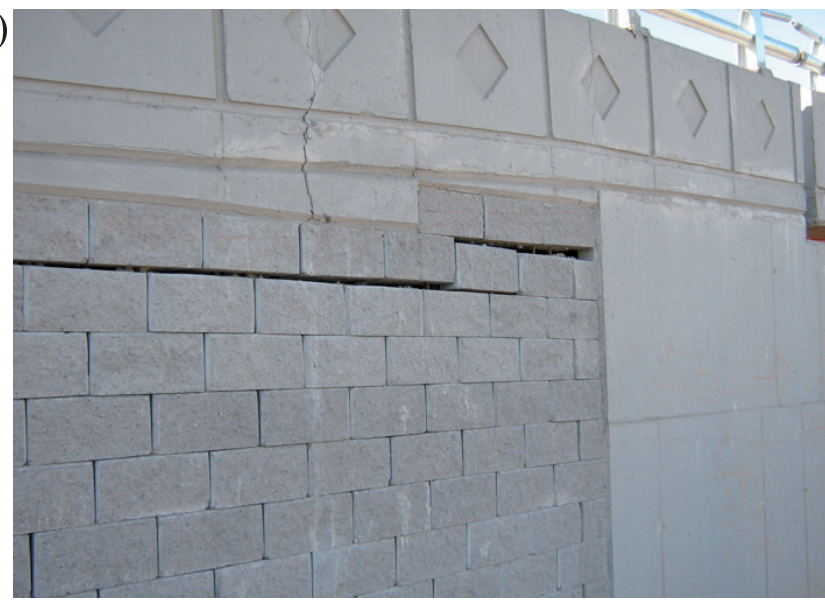

c)

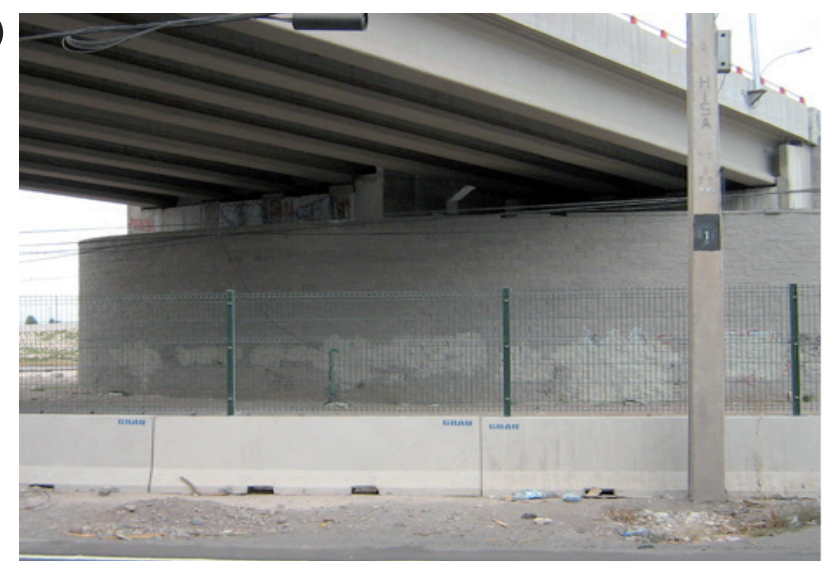

Figure 1: Pictures of geogrid reinforced soil walls after the 27F earthquake. a) No visible movement in bridge abutment wall in San Francisco de Mostazal, b) block vertical movement and fissures in Bonilla roundabout overpass and c) curved abutment in the overpass of Ruta 78 junction in Pajaritos Avenue without noticeable movement

in 1992 at Tanata performed successfully despite been located in one of the most severely shaken areas. They reported also other geogrid reinforced soil walls which performed satisfactorily. This led to the conclusion that this type of walls can be designed and built to resist strong earthquakes with minimum disturbance. After the 1995 Japanese earthquake this type of wall was used to replace damaged walls in Japan. The reconstruction of several railway earth retaining structures in bridges after the 2011 Tohoku earthquake, have also employed the solution of geogrid reinforced soil walls (Koseki et al., 2012).

This paper focuses on the static and seismic performance of a geogrid reinforced soil wall. This case is used as an example of a railway bridge's abutment built with geogrid reinforced soil walls which did not suffer major damage during the $27 \mathrm{~F}$ earthquake.

\section{Geogrid reinforced soil wall GRSW as bridge abutments}

The 27F 2010 earthquake in Chile gave the opportunity to study the performance of this type of solution under a strong seismic event. Segmental block-faced geosynthetic reinforced soil for bridge abutments have previously demonstrated satisfactory performance and very high load carrying capacity in serviceability conditions, i.e. under no strong seismic events and mostly abroad, particularly in the USA (e.g. Abu-Hejleh et al., 2000). This type of wall is easier to build and cheaper than other types of walls such as gravity or reinforced concrete cantilever retaining walls. It has also been recognised that GRSWs can improve bearing capacity when soft soils are encountered. This might even eliminate the option of deep foundations such as piles, which can have the advantage of reducing bridge bumps when entering or leaving a bridge (Helwany et al., 2003). A rigid bridge abutment (reinforced concrete walls) founded on piles can induce differential settlements between the bridge and the approaching embankment causing bridge bumps. However, the use of piles is justified when there are soft soils or when scour can occur.

The GRSW solution represents a soil mass covered with segmental block facing that assist in the retaining structure construction. This facing apart from an ornamental role does not give much structural resistance. Therefore, a GRSW abutment behaves differently than that of a rigid abutment over a rigid foundation. In a GRSW abutment, the whole structure (reinforcement, block facing, fill) acts as one element which support the bridge, i.e. as a big foundation. This big foundation can reduce the large loads imposed by the bridge transferring the same load in a much wider 
surface, hence diminishing stresses on the foundation soil. It is worth highlighting that there is not only a reduction of stresses transmitted to the subsoil reducing settlements too, but the settlements are share by the whole structure reducing differential settlements (Helwany et al., 2003). This response as one element may explain the favourable seismic response.

\section{Railway bridge Las Gaviotas}

The $55^{\circ}$ skewed bridge Las Gaviotas was built in 2003. It is located in the Interportuaria motorway joining Talcahuano and Penco and passes above the railway and an unpaved road between Concepción and Penco. Figures $2 \mathrm{a}$ and $2 \mathrm{~b}$ show pictures taken just after the 2010 earthquake of the GRSWs of $44 \mathrm{~m}$ long at the base and $8 \mathrm{~m}$ high under the bridge.

a)

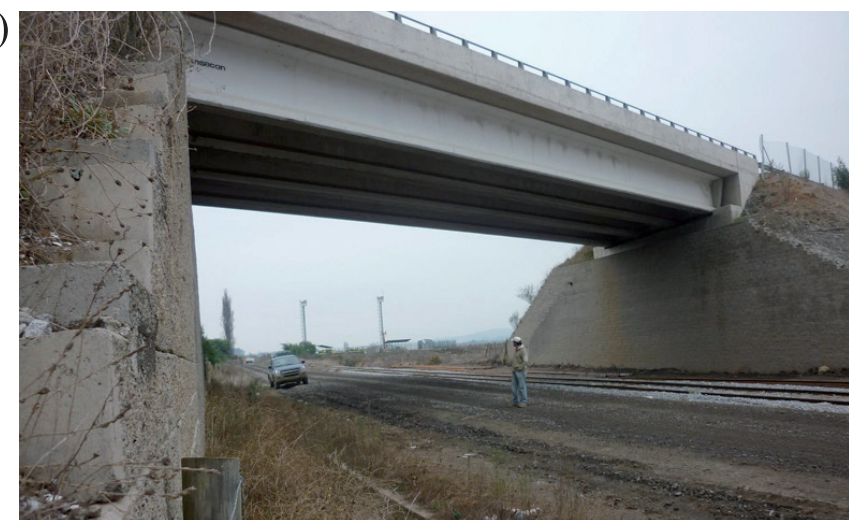

b)

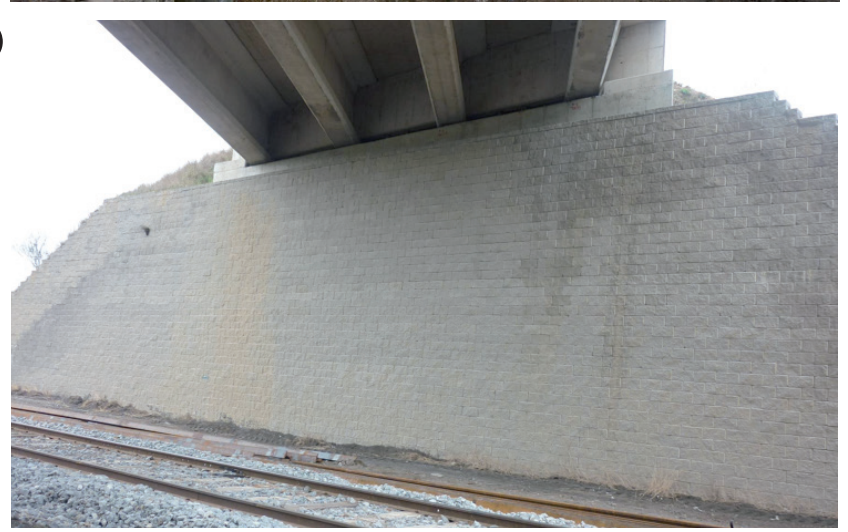

Figure 2: a) View of the motorway bridge Las Gaviotas over railway and road and b) view of the geogrid reinforced soil wall abutment

\section{Allowable stress design analysis of the GRSW wall \\ Static external stability}

This project is almost on the coast therefore closer to the subduction trench between the Nazca and Continental plates and around $100 \mathrm{~km}$ South from the 2010 earthquake epicentre in the town of Cobquecura. The foundation soil is poor, corresponding mainly to marine and fluvial deposits close to the stream and mouth of the Andalién River. Due to these deposits, piles were needed to increase the support of the bridge in addition to the GRSW. Four piles for each abutment were designed with $1 \mathrm{~m}$ diameter and $22.5 \mathrm{~m}$ depth. The geogrids were cut to leave room for the piles. Note that only the global seismic stability analysis (presented at the end), justifies the inclusion of piles. The external static stability was evaluated complying with force and moment equilibrium as shown in Figure 3. The following calculation procedure is based mainly on the recommendations of FHWA (2001) which adopt the allowable stress design ASD. Details of the calculations can be found in González (2015).

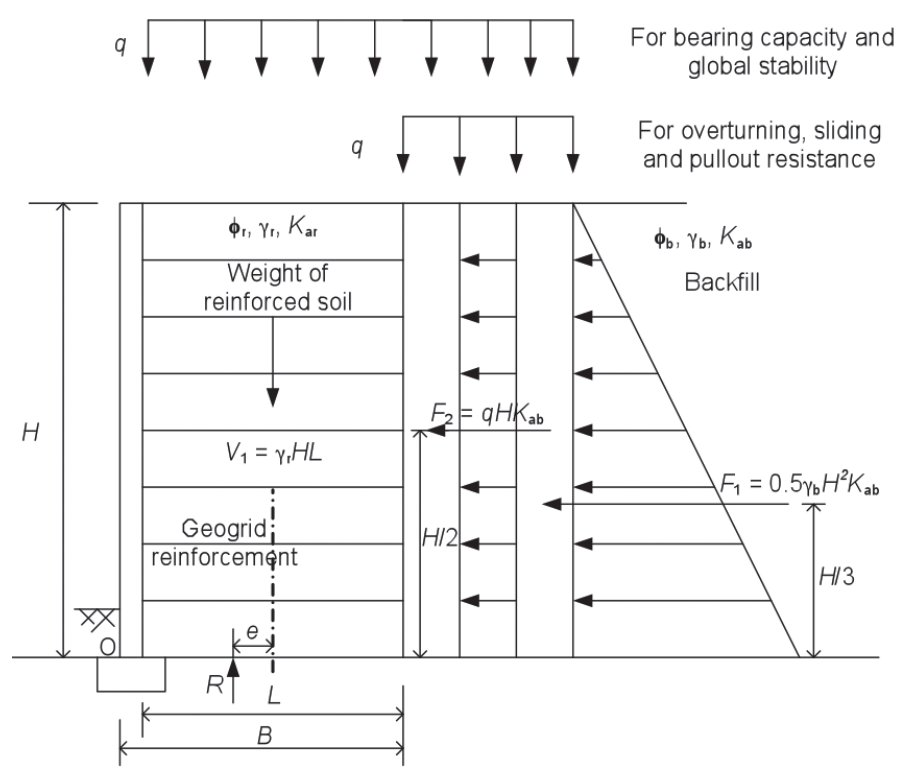

Figure 3: Static external force diagram of GRSW; $e$ : eccentricity, $R$ : resultant of vertical forces, $q$ : overburden

An initial value of $L=7 \mathrm{~m}$ was adopted for the geogrid length and the wall height $H=8 \mathrm{~m}$. It is worth pointing out that experimental and numerical results have shown that in presence of geogrids the distribution of the active lateral earth pressure reduces and forms an arch shaped distribution between geogrids in comparison with triangular distributions (e.g. Jacobs et al., 2016; Ruiz-Tagle and Villalobos, 2011a, 2001b). However, the Rankine theory was adopted for simplicity to calculate the active lateral earth pressure forces $F_{1}$ and $F_{2}$. For reinforced and backfill soil it was assumed the same angle of internal friction $\phi$ ' $=37^{\circ}$ and the same unit weight $\gamma=19.1 \mathrm{kN} / \mathrm{m}^{3}$. Thus, the 
resistant and overturning moment respect to $\mathrm{O}$ are:

$$
\begin{aligned}
& M_{\mathrm{R}}=\frac{1}{2}\left(V_{1}+q_{\mathrm{DL}} L\right) L=3911 \mathrm{kNm} / \mathrm{m} ; \\
& M_{\mathrm{O}}=\frac{1}{3} F_{1} H+\frac{1}{2} F_{2} H=555 \mathrm{kNm} / \mathrm{m}
\end{aligned}
$$

where $V_{1}$ is the weight of the reinforced soil, $q_{\mathrm{DL}}$ is a uniform dead load, $F_{1}$ and $F_{2}$ are active lateral earth forces. This results in an overturning factor of safety $\mathrm{FS}_{\mathrm{O}}=M_{\mathrm{R}} / M_{\mathrm{O}}$ $=6.8>2.0$. The sliding force $F_{\mathrm{S}}=F_{1}+F_{2}=152.6+36.6$ $=189.2 \mathrm{kN} / \mathrm{m}$ and the resistant force $F_{\mathrm{R}}=\left(V_{1}+q_{\mathrm{DL}} L\right) \tan \phi$ $=842 \mathrm{kN} / \mathrm{m}$ lead to a sliding factor of safety $\mathrm{FS}_{\mathrm{S}}=F_{\mathrm{R}} / F_{\mathrm{S}}$ $=4.5>1.5$.

The bearing capacity factor of safety $\mathrm{FS}_{\mathrm{B}}=q_{\mathrm{u}} / \sigma_{\mathrm{v}}$, assumes a Meyerhof stress distribution $\sigma_{\mathrm{v}}=R / L^{\prime}$, where $L^{\prime}=L^{-}$ $2 e, e=L / 2-\left(M_{\mathrm{R}}-M_{\mathrm{O}}\right) / R$, and $R=V_{1}+V_{2}=1072.6+$ $128.8=1201 \mathrm{kN} / \mathrm{m}$ is the vertical resultant force when $V_{2}$ corresponds to overburden loads such as traffic $q_{\mathrm{LL}}=12 \mathrm{kPa}$ and extra dead load $q_{\mathrm{DL}}=6.4 \mathrm{kPa}$. Then, the eccentricity $e$ $=0.71<1.17(=L / 6)$. Using Terzaghi's formulation with Vesic' $N_{\gamma}$ factor $\left(66.2\right.$ for $\phi^{\prime}=37^{\circ}$ and 22.4 for $\left.\phi^{\prime}=30^{\circ}\right)$, base width $B=L^{\prime}$ ' and neglecting depth effects results in $q_{\mathrm{u}}=0.5 L^{\prime} \gamma N_{\gamma}=3540 \mathrm{kPa}$ and $\mathrm{FS}_{\mathrm{B}}=16$ for $\phi^{\prime}=37^{\circ}>2.5$ and $q_{\mathrm{u}}=1198 \mathrm{kPa}, \mathrm{FS}_{\mathrm{B}}=6>2.5$ for $\phi^{\prime}=30^{\circ}$ (for soft foundation soil).

\section{Seismic external stability}

The seismic external stability can be evaluated by means of a pseudo static method as shown schematically in Figure 4. The dynamic active horizontal force imposed by the earthquake $P_{\mathrm{AE}}$ is added to the static horizontal forces due to active lateral earth pressure imposed by the retained soil and overburden. In addition, the reinforced soil mass applies a horizontal inertial force $P_{\mathrm{IR}}=m A_{\mathrm{m}}$, where $m$ is the mass of the active part of the reinforced soil section assumed with a base width of $0.5 H$ and $A_{\mathrm{m}}=(1.45-A) A$ is the maximum horizontal acceleration in the GRSW and $A$ is a free field maximum acceleration coefficient which in Concepción is assumed to be equal to $0.4 \mathrm{~g}$, value measured in the centre of Concepción in the 2010 earthquake (Boroschek et al., 2010). Therefore, the horizontal seismic coefficient is $A_{\mathrm{m}}$ $=K_{\mathrm{h}}=0.42$. The vertical seismic coefficient is assumed $K_{\mathrm{v}}$ $=0 . P_{\mathrm{AE}}$ is evaluated using the pseudo static MononobeOkabe method, then $\theta=\tan ^{-1}\left[K_{\mathrm{h}} /\left(1-K_{\mathrm{v}}\right)\right]=22.8^{\circ}$ and the seismic earth pressure coefficient $K_{\mathrm{AE}}=0.56$ and the
Coulomb static lateral earth pressure coefficient is $K_{\mathrm{A}}=$ 0.249 which results in $\Delta K_{\mathrm{AE}}=K_{\mathrm{AE}}-K_{\mathrm{A}}=0.315$ and the seismic increment in lateral load is $\Delta P_{\mathrm{AE}}=0.5 \gamma H^{2} \Delta K_{\mathrm{AE}}=$ $193.4 \mathrm{kN} / \mathrm{m}$. The $50 \%$ of $\Delta P_{\mathrm{AE}}$ is then $96.7 \mathrm{kN} / \mathrm{m}$ and the inertial force $P_{\mathrm{IR}}=m A_{\mathrm{m}}=(0.5 H) H \gamma A_{\mathrm{m}}=0.5 \gamma H^{2} A_{\mathrm{m}}=257.8$ $\mathrm{kN} / \mathrm{m}$, where $0.5 H$ is the assumed base width of the active mass of reinforced soil. The resistance force $F_{\mathrm{R}}$ is the same as in the static analysis, but in the sliding force $F_{\mathrm{S}}$, the $50 \%$ of seismic increment $0.5 \Delta P_{\mathrm{AE}}$ and the inertial force $P_{\mathrm{IR}}$ are added to the static lateral earth pressures $F_{1}$ and $F_{2}$. This results in a seismic factor of safety against sliding $\mathrm{FS}_{\mathrm{S}}=F_{\mathrm{R}} /$ $F_{\mathrm{S}}=842 / 543.6=1.55>1.13$. For the overturning stability, the resistance moment $M_{\mathrm{R}}$ is equal to the static case and in the overturning moment $\Delta P_{\mathrm{AE}}$ and $P_{\mathrm{IR}}$ are included as follows: $M_{\mathrm{O}}=F_{1} H / 3+\left(F_{2}+P_{\mathrm{IR}}\right) H / 2+0.5 \Delta P_{\mathrm{AE}} 0.6 H=$ $2050 \mathrm{kNm} / \mathrm{m}$, which results in an overturning factor of safety $\mathrm{FS}_{\mathrm{o}}=M_{\mathrm{R}} / M_{\mathrm{O}}=3911 / 2050=1.9>1.5$.

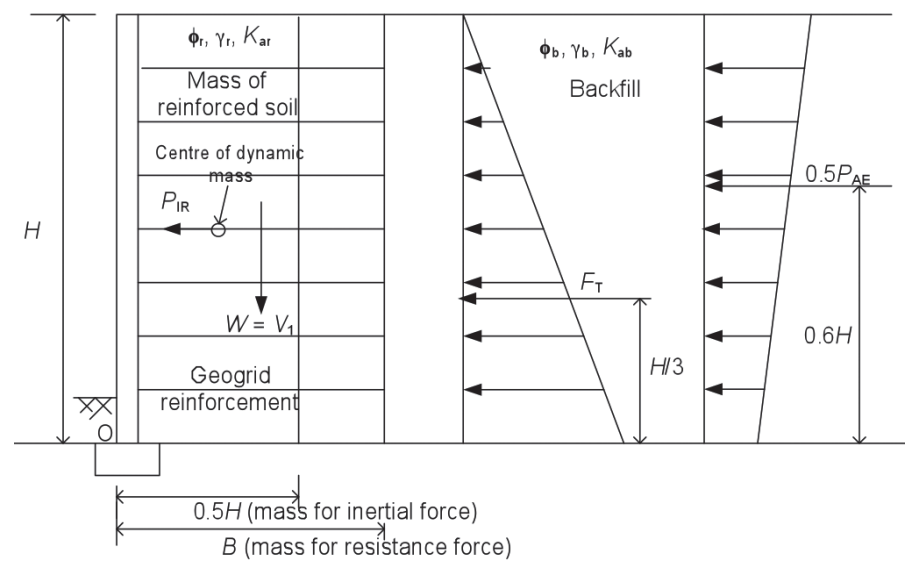

Figure 4: Seismic external force diagram for the GRSW stability

For the applied stress distribution and seismic bearing capacity calculations, the only difference with the static calculation is the eccentricity $e$ restricted to $L / 3$ rather than $L / 6$. Thus $e=M_{\mathrm{o}} / R$, hence $e=2050 / 1201=1.7 \mathrm{~m}<2.33$ $\mathrm{m}$, where the base width $L^{\prime}=L-2 e=3.6 \mathrm{~m} \rightarrow \sigma_{\mathrm{v}}=R / L$, $=1201 / 3.6=334 \mathrm{kPa}$. It is worth mentioning that from theoretical and numerical analyses, it can be found that the coefficients of bearing capacity reduce with the increase of the horizontal seismic coefficient $K_{\mathrm{h}}$ (e.g. Soubra, 1999). However, it was assumed for simplicity that the bearing capacity coefficients do not change for a seismic condition. Hence, $q_{\mathrm{u}}=0.5 L^{\prime} \gamma N_{\gamma}=2213 \mathrm{kPa}$ and $\mathrm{FS}_{\mathrm{B}}=6.6>1.88$ for $\phi^{\prime}=37^{\circ}$ and $q_{\mathrm{u}}=749 \mathrm{kPa}, \mathrm{FS}_{\mathrm{B}}=2.2>1.88$ for $\phi^{\prime}=30^{\circ}$ (for soft foundation soil). 
Figures $5 \mathrm{a}$ and $5 \mathrm{~b}$ show the variation of the factor of safety against sliding FSs and overturning FSo with the free field maximum acceleration $A$ and also with the angle of internal friction $\phi$ ' (the same for reinforced, fill and foundation soil). It can be observed that factors of safety are above 1.0 , except for FSs when $\phi^{\prime}<34^{\circ}$ and $A>0.4 \mathrm{~g}$. Therefore, according to these calculations overturning failure should not occur even for high values of accelerations and low values of angles of friction. However, sliding may occur in case of low angle of friction and high acceleration values.

a)

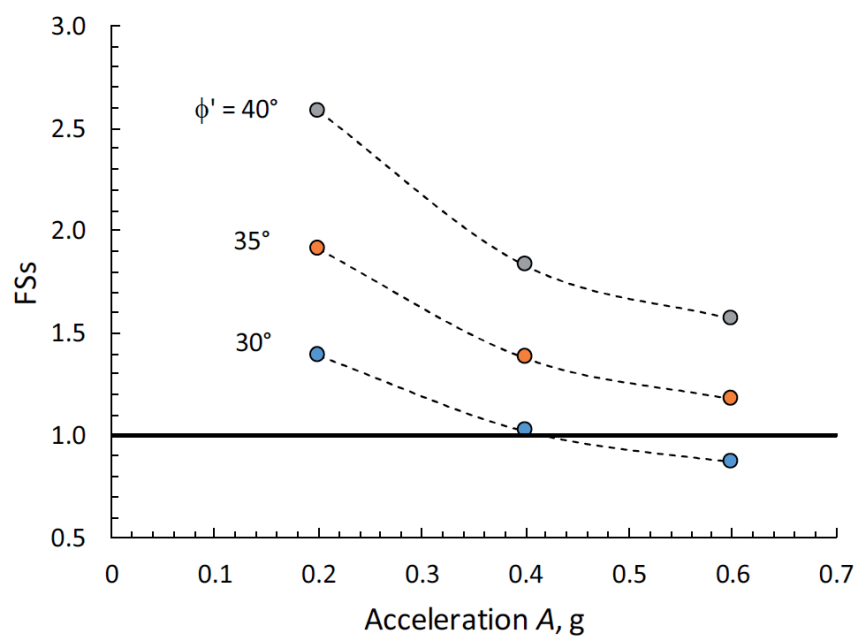

b)

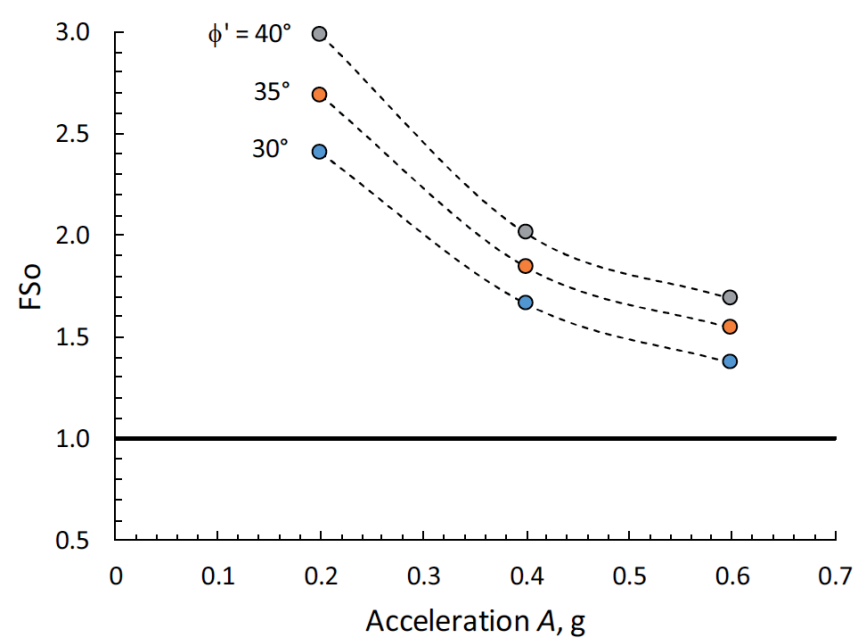

Figure 5: Variation of the factor of safety versus the acceleration and angle of friction a) against sliding and b) overturning

\section{Static internal stability: tension resistance}

Internal stability requires that each reinforcement layer resists a portion of the lateral earth pressure assumed over a tributary area $S_{\mathrm{v}}$. Then geogrids have to be designed with enough allowable force to not break under tensile stresses. The maximum tension load in each geogrid due to the horizontal stress can be determined by (FHWA, 2001):

$T_{\max }=\sigma_{\mathrm{h}} S_{\mathrm{v}}=\sigma_{\mathrm{h}} V_{\mathrm{i}}=K_{\mathrm{a}}\left(\gamma d_{\mathrm{i}}+q_{\mathrm{LL}}+q_{\mathrm{DL}}\right) V_{\mathrm{i}}$

where $K_{\mathrm{a}}$ is the Rankine lateral earth pressure coefficient, $\gamma$ is the fill unit weight, $d_{\mathrm{i}}=H-h_{\mathrm{i}}$, where $H$ is the wall height and $h_{\mathrm{i}}$ is the block height equal to $0.193 \mathrm{~m}$, and $S_{\mathrm{v}}$ is the vertical spacing between geogrids which can be calculated by $V_{\mathrm{i}}=0.5\left(h_{\mathrm{i}+1}-h_{\mathrm{i}}\right)+0.5\left(h_{\mathrm{i}}-h_{\mathrm{i}-1}\right)$. Table 1 summarizes the results of $T_{\max }$ and the results of the factor of safety of tension resistance, or geogrid rupture, for each geogrid, where FS $=T_{\text {all }} / T_{\max }$. The long-term design strength or allowable strength $T_{\text {all }}$ can be estimated for each type of geogrid using the following expression:

$$
T_{\mathrm{all}}=\frac{T_{u l t}}{R F_{c r} R F_{d u} R F_{i n}} R_{\mathrm{c}}
$$

where $T_{\text {ult }}$ is the ultimate tensile strength per unit width, $R F_{c r}$ is a reduction factor for creep of the geogrid normally between 2.0 and 3.0 (assumed 2.6), $R F_{d u}$ is a durability reduction factor for chemical and biological degradation normally between 1.0 and 1.5 (1.0 used) and $R F_{\text {in }}$ is a reduction factor for damage caused by installation, normally between 1.05 and 1.4 (1.05 used). $R_{\mathrm{c}}$ is a coverage ratio factor equal to the geogrid width divided by the geogrid width plus the spacing between geogrids. For zero spacing $R_{\mathrm{c}}=1.0$ and for a $1.33 \mathrm{~m}$ geogrid width and $0.29 \mathrm{~m}$ of spacing $R_{\mathrm{c}}=0.82$. The values of $T_{\mathrm{ult}}$ can be determined in laboratory tests for each type of geogrid following for example ASTM D6637 (2015). Values for the reduction factors can be found in FHWA (2009). In general, geogrid manufacturers provide values of these parameters.

\section{Pullout resistance}

Stability against pullout of the geogrids is usually assessed through the required geogrid length. This is carried out using the geogrid length in the embedment or resistance zone $L_{\mathrm{e}}$, where the geogrid is beyond the failure surface (active zone) and can effectively resist. A criterion based on the maximum reinforcement tension can be established as (FHWA, 2001):

$$
L_{e} \geq \frac{F S_{p o} T_{\max }}{2 C_{i} \tan \phi\left(\gamma d_{i}+q_{D L}\right) R_{c} \alpha} \geq 1 \mathrm{~m}
$$


Table 1: Verification of each geogrid static tension resistance

\begin{tabular}{|c|c|c|c|c|c|c|c|c|c|}
\hline No. layer & No. of blocks & $h_{\mathrm{i}}, \mathrm{m}$ & $d_{\mathrm{i}}, \mathrm{m}$ & $V_{\mathrm{i}}, \mathrm{m}$ & $\begin{array}{c}T_{\max }, \\
\mathrm{kN} / \mathrm{m}\end{array}$ & $R_{\mathrm{c}}$ & geogrid & $\begin{array}{c}T_{\text {all }}, \\
\mathrm{kN} / \mathrm{m}\end{array}$ & $\mathrm{FS}>1.5$ \\
\hline 1 & 2 & 0.193 & 7.817 & 0.39 & 16.11 & 0.82 & UX3 & 34.24 & 2.2 \\
\hline 2 & 3 & 0.579 & 7.431 & 0.48 & 19.26 & 0.82 & UX3 & 34.24 & 1.8 \\
\hline 3 & 3 & 1.158 & 6.852 & 0.58 & 21.51 & 0.82 & UX3 & 34.24 & 1.6 \\
\hline 4 & 1 & 1.737 & 6.273 & 0.39 & 13.28 & 0.82 & UX3 & 34.24 & 2.6 \\
\hline 5 & 2 & 1.930 & 6.080 & 0.29 & 9.69 & 1.00 & UX3 & 41.76 & 4.3 \\
\hline 6 & 1 & 2.316 & 5.694 & 0.29 & 9.16 & 0.82 & UX3 & 34.24 & 3.7 \\
\hline 7 & 2 & 2.509 & 5.501 & 0.29 & 8.90 & 1.00 & BX1 & 19.20 & 2.2 \\
\hline 8 & 1 & 2.895 & 5.115 & 0.29 & 8.37 & 0.82 & UX3 & 34.24 & 4.1 \\
\hline 9 & 2 & 3.088 & 4.922 & 0.29 & 8.10 & 1.00 & $\mathrm{BX} 2$ & 27.00 & 3.3 \\
\hline 10 & 1 & 3.474 & 4.536 & 0.29 & 7.57 & 1.00 & UX2 & 25.64 & 3.4 \\
\hline 11 & 2 & 3.667 & 4.343 & 0.29 & 7.30 & 1.00 & BX1 & 19.20 & 2.6 \\
\hline 12 & 1 & 4.053 & 3.957 & 0.29 & 6.77 & 1.00 & UX2 & 25.64 & 3.8 \\
\hline 13 & 2 & 4.246 & 3.764 & 0.29 & 6.51 & 1.00 & BX1 & 19.20 & 3.0 \\
\hline 14 & 1 & 4.632 & 3.378 & 0.29 & 5.97 & 0.82 & UX2 & 21.03 & 3.5 \\
\hline 15 & 2 & 4.825 & 3.185 & 0.29 & 5.71 & 1.00 & BX1 & 19.20 & 3.4 \\
\hline 16 & 1 & 5.211 & 2.799 & 0.29 & 5.18 & 0.82 & UX1 & 17.42 & 3.4 \\
\hline 17 & 2 & 5.404 & 2.606 & 0.29 & 4.91 & 1.00 & BX1 & 19.20 & 3.9 \\
\hline 18 & 1 & 5.790 & 2.220 & 0.29 & 4.38 & 0.82 & UX1 & 17.42 & 4.0 \\
\hline 19 & 2 & 5.983 & 2.027 & 0.29 & 4.11 & 1.00 & BX1 & 19.20 & 4.7 \\
\hline 20 & 1 & 6.369 & 1.641 & 0.29 & 3.58 & 0.82 & UX1 & 17.42 & 4.9 \\
\hline 21 & 2 & 6.562 & 1.448 & 0.29 & 3.32 & 1.00 & BX1 & 19.20 & 5.8 \\
\hline 22 & 1 & 6.948 & 1.062 & 0.29 & 2.79 & 0.82 & UX1 & 17.42 & 6.3 \\
\hline 23 & 2 & 7.141 & 0.869 & 0.29 & 2.52 & 1.00 & BX1 & 19.20 & 7.6 \\
\hline 24 & 3 & 7.527 & 0.483 & 0.68 & 4.64 & 1.00 & UX1 & 21.25 & 4.6 \\
\hline
\end{tabular}

Note: BX1 used for the connection of blocks, they are not really intended to resist tension

where $F S_{\mathrm{po}}$ is the pullout factor of safety equal to 1.5 , the number 2 corresponds to the reinforcement effective unit perimeter for sheets and because the edges are neglected it is 2 for strips and grids. $C_{\mathrm{i}}$ is a soil-geogrid interaction coefficient which should be measured in laboratory tests. It is assumed generally as 2/3 by FHWA (2009). Das (2012) proposes values of $0.75-0.8$ for gravel and sandy gravel, 0.7-0.75 for well graded sand and gravelly sand and 0.55 0.6 for fine sand and silty sand. In this work values of $C_{\mathrm{i}}=$ 0.75 are adopted for UX1 and UX3 and 0.8 for the other geogrids (González, 2015). $\alpha$ is a scale effect correction factor applicable to highly extensible reinforcements, assumed here as 1.0, see FHWA (2009) for other cases. Table 2 shows that $L_{\mathrm{e}}<1$. Hence $L_{\mathrm{e}}=1.0 \mathrm{~m}$.

The geogrid length inside the active zone $L_{\mathrm{a}}$ comes from the wedge-shaped failure surface, thus,

$$
L_{\mathrm{a}}=\left(H-d_{\mathrm{i}}\right) \tan (90-\psi)-\left(H-d_{\mathrm{i}}\right) \tan \omega
$$

Where $\psi=45+\phi / 2=63.5^{\circ}$, is the angle of the failure surface and $\omega$ is the wall inclination angle, in this case $\omega=$
Table 2: Verification of each geogrid static length

\begin{tabular}{|c|c|c|c|}
\hline No.layer & $L_{\mathrm{e}}, \mathrm{m}$ & $L_{\mathrm{a}}, \mathrm{m}$ & $L_{\text {Total }} \mathrm{m}$ \\
\hline 1 & 0.157 & 0.10 & 1.10 \\
\hline 2 & 0.197 & 0.29 & 1.29 \\
\hline 3 & 0.237 & 0.58 & 1.58 \\
\hline 4 & 0.159 & 0.87 & 1.87 \\
\hline 5 & 0.098 & 0.96 & 1.96 \\
\hline 6 & 0.121 & 1.15 & 2.15 \\
\hline 7 & 0.099 & 1.25 & 2.25 \\
\hline 8 & 0.122 & 1.44 & 2.44 \\
\hline 9 & 0.100 & 1.54 & 2.54 \\
\hline 10 & 0.108 & 1.73 & 2.73 \\
\hline 11 & 0.102 & 1.83 & 2.83 \\
\hline 12 & 0.109 & 2.02 & 3.02 \\
\hline 13 & 0.103 & 2.12 & 3.12 \\
\hline 14 & 0.136 & 2.31 & 3.31 \\
\hline 15 & 0.105 & 2.41 & 3.41 \\
\hline 16 & 0.140 & 2.60 & 3.60 \\
\hline 17 & 0.109 & 2.69 & 3.69 \\
\hline 18 & 0.145 & 2.89 & 3.89 \\
\hline 19 & 0.113 & 2.98 & 3.98 \\
\hline 20 & 0.153 & 3.18 & 4.18 \\
\hline 21 & 0.121 & 3.27 & 4.27 \\
\hline 22 & 0.169 & 3.46 & 4.46 \\
\hline 23 & 0.136 & 3.56 & 4.56 \\
\hline 24 & 0.394 & 3.75 & 4.75 \\
\hline
\end{tabular}


$0^{\circ}$. The total minimum length is then $L=L_{e}+L_{\mathrm{a}}$, which for the bottom layer becomes $4.75 \mathrm{~m}$.

Seismic internal stability: tension resistance and pullout Tension resistance under seismic events can be assessed using the following expression of the factor of safety (FHWA, 2001):

$$
F S=\frac{T_{u l t} R_{c}}{T_{\max } R F+T_{m d} R F_{d u} R F_{i n}}
$$

where

$$
T_{u l t}=S_{r s}+S_{r t}=\frac{0.75 F S R F T_{\max }}{R_{c}}+\frac{0.75 T_{m d} F S R F_{d u} R F_{i n}}{R_{c}}
$$

where $0.75 F S$ reflects the reduction of the static factor of safety $F S=1.5$ by 0.75 , i.e. the seismic factor of safety is 1.125. $R F$ is the combined strength reduction factor for potential long-term degradation caused by creep, chemical ageing and installation damage $R F=R F_{c r} R F_{d u} R F_{\text {in }}=2.73$ (1.05 for BX). $T_{\max }$ is the maximum static tension load in each geogrid due to the horizontal stress defined as before in (2) and $T_{\mathrm{md}}$ arises to incorporate the dynamic component of loading, although not including creep effects. The active wedge is assumed to generate an internal dynamic inertial force $P_{\mathrm{I}}=A_{\mathrm{m}} W_{\mathrm{A}}$, where as before $A_{\mathrm{m}}=K_{\mathrm{h}}=0.42$ is a seismic coefficient and $W_{\mathrm{A}}$ is the weight of the active zone, $P_{\mathrm{I}}=0.42^{1} \frac{1}{2} \gamma H^{2}[\tan (90-\psi)-\tan \omega]=128 \mathrm{kN} / \mathrm{m}$. The dynamic increment induced by the inertial force in each reinforcement can be calculated as:

$$
T_{m d}=P_{I} \frac{L_{e i}}{\sum_{i=1}^{n} L_{e i}}=P_{I} \frac{L-L_{a i}}{\sum_{i=1}^{n}\left(L-L_{a i}\right)}
$$

where $L=7 \mathrm{~m}$ is the design length and $L_{\mathrm{a}}$ is embedment length in the active zone, previously calculated for the static analysis. Table 3 shows results of $L_{\mathrm{ei}}$ from $L_{\mathrm{a}}$ values shown in Table 2, allowing the calculation of $T_{\mathrm{md}}$ and consequently, $T_{\text {total }}=T_{\text {max }}+T_{\text {md }}$ ( $T_{\text {max }}$ values are shown in Table 1). The required ultimate tensile resistance of the geogrids is $T_{\mathrm{ult}}=S_{\mathrm{rs}}+S_{\mathrm{rt}}$, which when compared with the available $T_{\text {ult }}$ given by each geogrid allows the calculation of the factor of safety $F S=T_{\text {ult,available }} / T_{\text {ult,required }} . F S$ from (6) results in 1.125 which is the bottom line for $F S$, since the values shown in Table 3 are equal or larger than that.
The seismic pullout resistance $T_{\mathrm{po}}$ is determined by reducing the static friction coefficient $C_{\mathrm{i}} \tan \phi$ by $20 \%$.

$$
T_{p o}=\frac{1}{0.75 F S_{p o}} 0.8 C_{i} \tan \phi\left(\gamma d_{i}+q_{D L}\right) L_{e} 2 R_{c} \alpha \geq T_{\text {total }}
$$

Table 3 shows that the values of $T_{\mathrm{po}}$ are much larger than

\begin{tabular}{|c|c|c|c|c|c|c|c|c|c|}
\hline $\begin{array}{l}\text { No. } \\
\text { layer }\end{array}$ & $\begin{array}{c}L_{\mathrm{ei}}, \\
\mathrm{m}\end{array}$ & $\begin{array}{c}\begin{array}{c}T_{\mathrm{md}} \\
\mathrm{kN} / \mathrm{m}\end{array} \\
\end{array}$ & $\begin{array}{r}T_{\text {total }}, \\
\mathrm{kN} / \mathrm{m}\end{array}$ & $\begin{array}{c}S_{\mathrm{rr}}, \\
\mathrm{kN} / \mathrm{m}\end{array}$ & $\begin{array}{c}S_{\mathrm{rt}}, \\
\mathrm{kN} / \mathrm{m}\end{array}$ & $\begin{array}{c}T_{\text {ult }} \text { 'required } \\
\mathrm{kN} / \mathrm{m}\end{array}$ & $\begin{array}{c}T_{\text {ult' }}{ }_{\text {available }} \\
\mathrm{kN} / \mathrm{m}\end{array}$ & FS & $\begin{array}{c}T_{\mathrm{po}}, \\
\mathrm{kN} / \mathrm{m}\end{array}$ \\
\hline 1 & 6.90 & 7.45 & 23.57 & 60.35 & 10.74 & 71.09 & 114 & .6 & 757 \\
\hline 2 & 5.71 & 7.25 & 26.50 & 72.13 & 10.44 & 82.57 & 11 & 4 & 701 \\
\hline 3 & 6.42 & 6.93 & 28.45 & 80.58 & 9.99 & ונ. & 114 & 1.3 & 621 \\
\hline 4 & 6.13 & 6.62 & 19.90 & 49.74 & 9.54 & 59.28 & 114 & 1.9 & 545 \\
\hline 5 & 6.04 & 6.52 & 16.21 & 29.77 & 7.70 & 37 & 11 & 3.0 & 635 \\
\hline 6 & 5.85 & 6.31 & 15.47 & 34.32 & 9.09 & 43.41 & 114 & 2.6 & 474 \\
\hline 7 & 5.75 & 6.21 & 15.10 & 10.01 & 6.98 & 16.99 & 19.2 & 1.1 & 550 \\
\hline 8 & 5.56 & 6.00 & 14.37 & 31.33 & 8.64 & 39.97 & 11 & 2 & 407 \\
\hline 9 & .46 & 5.90 & 14.00 & 9.11 & 6.63 & 15.74 & 19.2 & 1 & 471 \\
\hline 10 & 5.27 & 5.69 & 13.26 & 23.25 & 6.72 & 29.97 & 70 & 2.3 & 395 \\
\hline 11 & 5.17 & 5.58 & 12.89 & 8.22 & 6.28 & 14.50 & 19. & 1.3 & 397 \\
\hline 12 & 4.98 & 5.38 & 12.15 & 20.80 & 6.35 & 27 & 70 & 2. & 329 \\
\hline 13 & 4.88 & 5.27 & 11.78 & 7.32 & 5.93 & 13.25 & 19.2 & 1.5 & 328 \\
\hline 14 & 4.69 & 5.06 & 11.04 & 22.38 & 7.30 & 29.68 & 70 & 2.4 & 220 \\
\hline 15 & 4.59 & 4.96 & 10.67 & 6.42 & 5.58 & 12. & 19 & 1.0 & 26 \\
\hline 16 & 4.40 & 4.75 & 9.93 & 19.39 & 6.85 & 26.24 & 58 & 2.2 & 174 \\
\hline 17 & 4.31 & 4.65 & 9.56 & 5.53 & 5.23 & 10.76 & 19.2 & 1.8 & 208 \\
\hline 18 & 4.11 & 4.44 & 8.82 & 16.41 & 6.40 & 22.81 & 58 & 2.5 & 133 \\
\hline 19 & 4.02 & 4.34 & 8.45 & 4.63 & 4.88 & 9.51 & 19.2 & 2.0 & 156 \\
\hline 20 & 3.82 & 4.13 & 7.71 & 13.42 & 5.95 & 19.37 & 58 & 3 & 95 \\
\hline 21 & 3.73 & 4.03 & 7.34 & 3.73 & 4.53 & 0.20 & 19.2 & 2.3 & 109 \\
\hline 22 & 3.54 & 3.82 & 6.60 & 10.44 & 5.50 & 15.94 & 58 & 3.6 & 62 \\
\hline 23 & 3.44 & 3.71 & 3 & 2.84 & 4.18 & 2 & 19.2 & 2.7 & 68 \\
\hline 24 & 3.25 & 3.51 & 8.15 & 14.26 & 4.14 & 18.40 & 58 & 3.2 & 41 \\
\hline
\end{tabular}
$T_{\text {total }}$, therefore there is enough seismic pullout resistance for the design proposed.

Table 3: Seismic tension and pullout resistance by layer

\section{LRFD methodologies}

The previous analyses were based on the method of allowable stress design ASD, where uncertainty in applied loads and material resistance is incorporated in a factor of safety. Another method of analysis is the load and resistance factor design LRFD, which accounts for uncertainty in resistance and load using pre-established factors. This methodology has been adopted by FHWA (2009), where the design consists in applying limit states for different 
cases of load and resistance combinations under static and seismic conditions. Load combinations include permanent and transient loads using minimum and maximum load factors, where the more critical combinations are selected. The LRFD methodology considers the evaluation of the external and internal stability analysis of MSE walls as in ASD analyses. The British norm BS 8006 (2010) is also based on the limit state philosophy, in particular the ultimate and service limit state, using partial factors. This methodology is very similar to that of the LRFD adopted by FHWA (2009), in respect to the increase of loads and reduction of resistance as well as using different load combinations. A comparison of these methods can be found in Galindo (2014). The following results based on FHWA (2009) and BS 8006 (2010) have been carried out using the software Geo5 (2015). Figure 6a shows results of the variation of the static factor of safety against sliding versus angle of friction comparing the three design methodologies. FHWA (2001) corresponds to the ASD design method explained before, FHWA (2009) is for the LRFD method under the most critical conditions and BS 8006 (2010) applies limit state analysis. It can be observed that although results are different, the trend is similar and factor of safety values are above 1 . The same can be observed in Figures $6 \mathrm{~b}$ and $6 \mathrm{c}$ for the static overturning and bearing capacity factors of safety. The lowest values of factor of safety are given by FHWA (2009).

The results of seismic factor of safety variation with the angle of friction are shown in Figures $7 \mathrm{a}, 7 \mathrm{~b}$ and $7 \mathrm{c}$. In general, it can be noticed that the values of factors of safety diminish, reaching values below 1.0 for sliding and bearing capacity when angles of frictions are below $32^{\circ}$. Although the three methods have different results, they provide almost the same trend and for angles of friction above $35^{\circ}$, they indicate that stability is reached with a factor of safety of at least 1.2.

\section{Global stability analysis}

The GRSW can be subjected to instability conditions from outside the reinforced structure that can pass through the GRSW. This problem is normally analysed using slope stability analysis tools. Figure 8 shows the results of a global static stability analysis considering the geogrids and soil properties. A Bishop method for the calculation of the a)

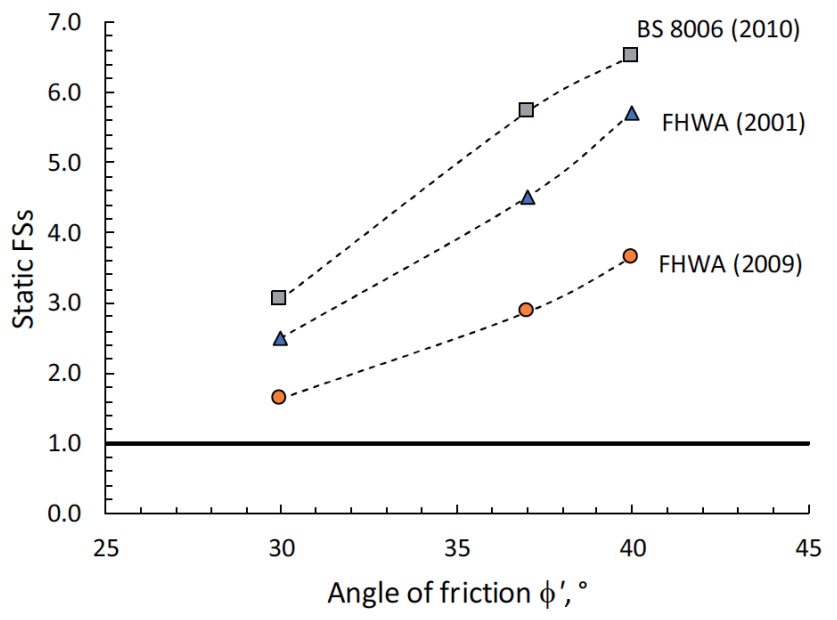

b)

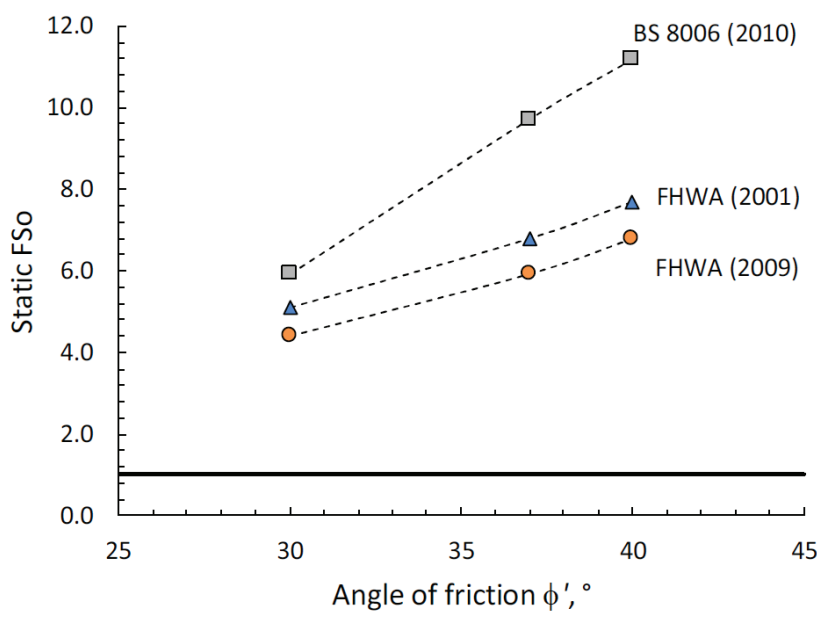

c)

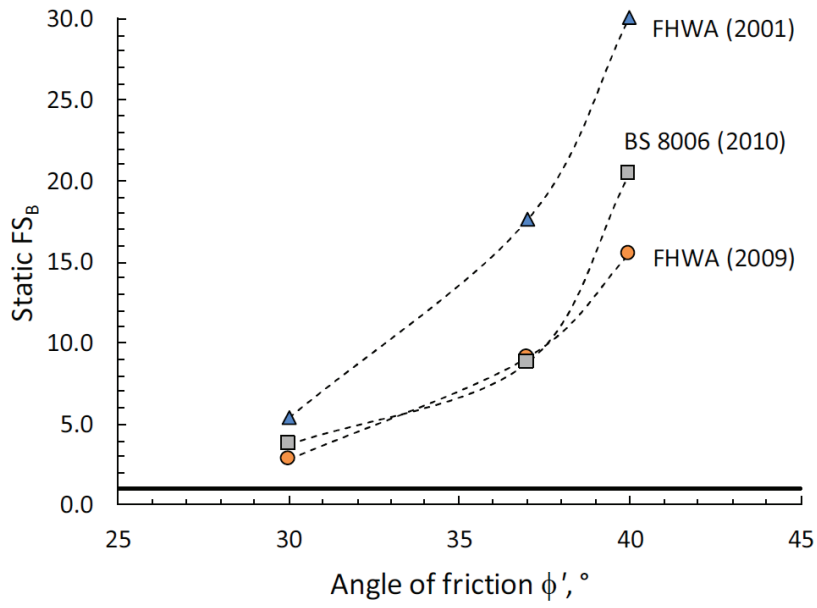

Figure 6: Variation of the static factor of safety with the angle of friction for different calculation methodologies, a) against sliding, b) overturning and c) bearing capacity

sliding factor of safety is adopted, where for the minimum global factor of safety of 1.64 the potential failure surface develops in the wall toe and moves upwards through the reinforcements. 
a)

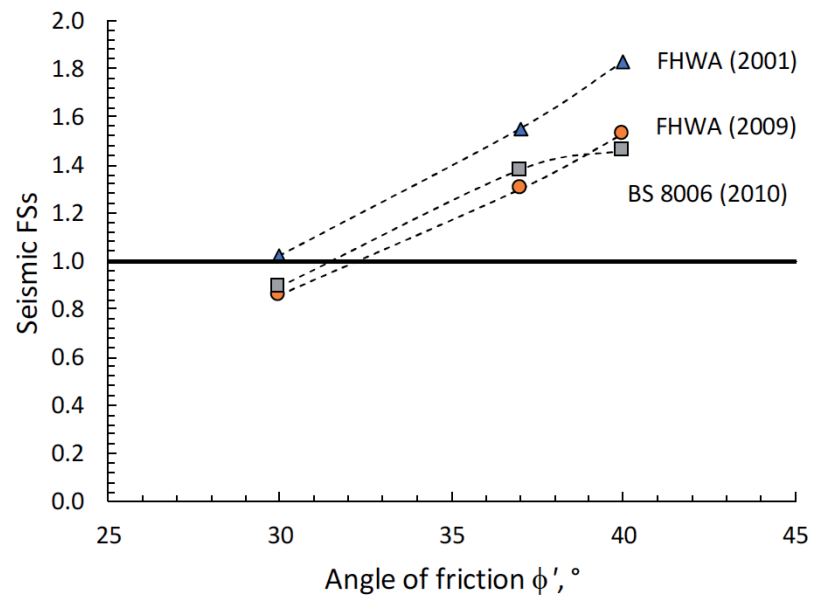

b)

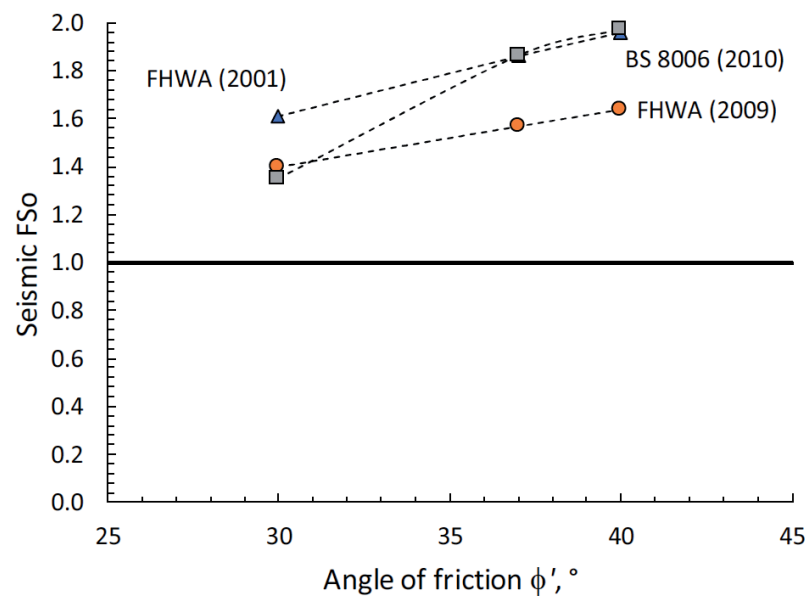

c)

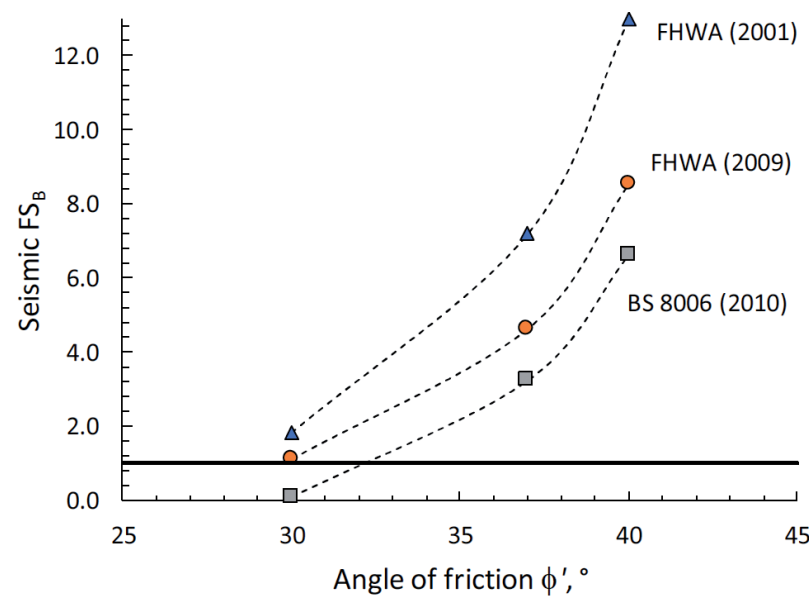

Figure 7: Variation of the seismic factor of safety with the angle of friction for different calculation methodologies, a) against sliding, b) overturning and c) bearing capacity

Figure 9 shows a pseudo-static analysis adopting $K_{\mathrm{h}}=$ 0.42 , resulting in a factor of safety of 0.97 . Since there was no noticeable damage in Las Gaviotas GRSW, let alone failure, a possible reason is that the analysis shown in Figure 9 does not include the piles which may have acted as an extra reinforcement. Other possible reason is that a

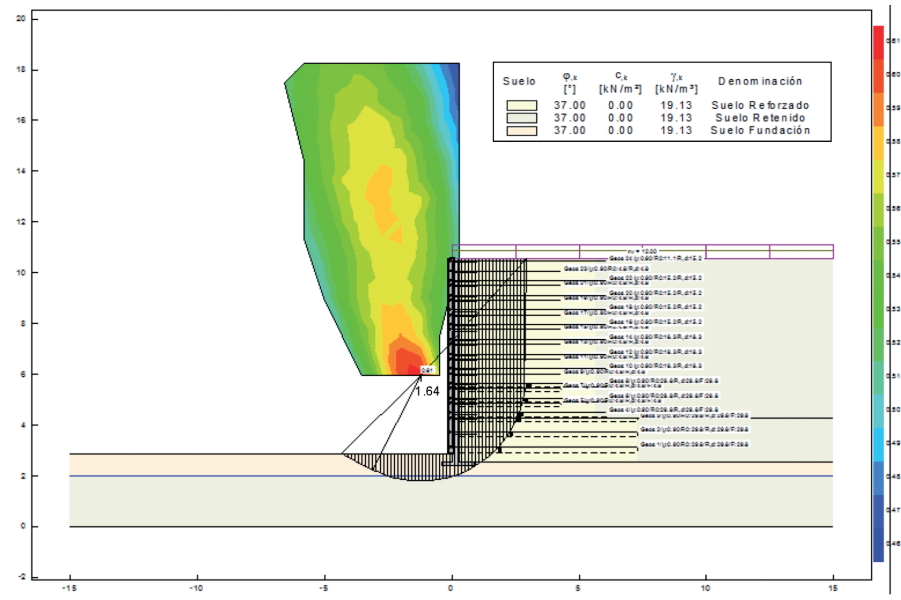

Figure 8: Static global stability analysis with software GGU (2015), $\mathrm{FS}_{\mathrm{G}}=1.64$

ground maximum acceleration less than $0.42 \mathrm{~g}$ occurred in the site. Other reason could be that the shear strength properties of the soil, specially the soil in contact with the geogrids and behind them, may have mobilized friction angle values higher than $37^{\circ}$. This latter explanation has been pointed out before as highly likely related to the favourable performance of GRSW in Japan (Tatsuoka et al., 1998).

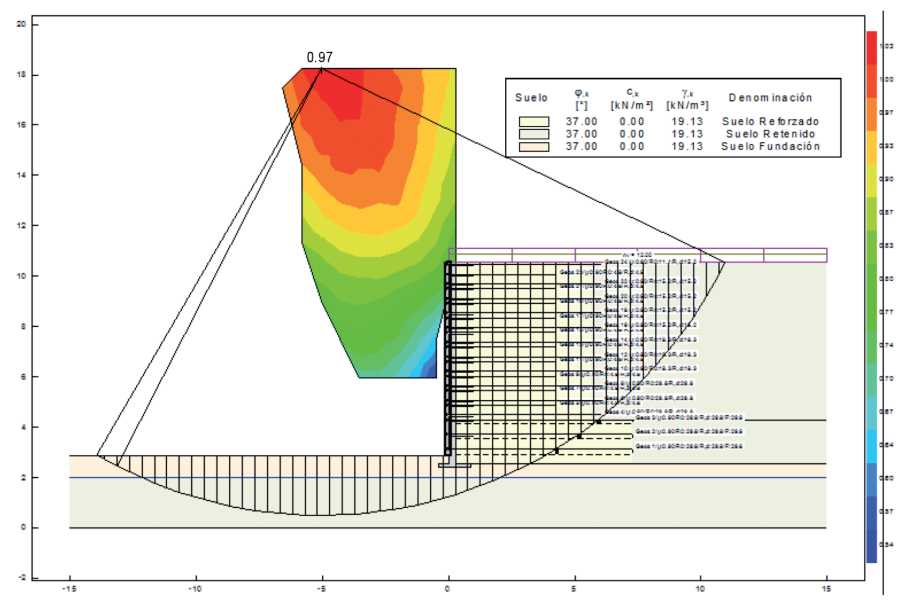

Figure 9: Pseudo-static global stability analysis with software GGU (2015), $\mathrm{FS}_{\mathrm{G}}=0.97$

\section{Final comments}

This work presented a back-calculation of a geogrid reinforced soil wall GRSW designed as abutment for Las Gaviotas Bridge after the occurrence in 2010 of the 8.8 moment magnitude earthquake in Concepción, Chile. This structure did not suffer any noticeable damage during the earthquake. The calculation procedures are mainly based on the allowable stress design ASD approach by FHWA 
(2001) recommendations. The results of this re-assessment shows that static and seismic stability comply with external and internal stability. Other calculation procedures were also performed for Las Gaviotas Bridge case such as the load and resistance factor design LRFD adopted by FHWA (2009) and the limit state method also with load factors and load combinations adopted by BS 8006 (2010). Although, some differences in the results were found compared with those obtained using the ASD approach, in general, they also comply with external and external and static and seismic stability. It was found that instability problems can appear in case of maximum accelerations larger than $0.4 \mathrm{~g}$ and soil angles of frictions below $34^{\circ}$. A factor of safety below 1.0 was also found in the seismic global stability analysis for a horizontal acceleration of $0.42 \mathrm{~g}$ and angle of friction of $37^{\circ}$. This situation led to the decision of including piles for the improvement of the abutment and bridge seismic global stability. Further research is needed to include arch effects in the calculation of lateral active earth pressure between geogrids as well as using seismic bearing capacity coefficients. Moreover, it would be important to evaluate displacements numerically and experimentally in field tests or ideally monitoring real GRSWs.

\section{References}

Abu-Hejleh, N., Wang, T. and Zornberg, J.G. (2000). Performance of geosynthetic-reinforced walls supporting bridge and approaching roadway structures. In Advances in Transportation and Geoenvironmental Systems Using Geosynthetics, ASCE, 218-243

ASTM D6637 (2015). Standard test method for determining tensile properties of geogrids by the single or multi-rib tensile method. West Conshohocken, PA, USA

Boroschek, R.L., Soto, P. and Leon, R. (2010). Maule Region Earthquake, 27 February 2010, Mw 8.8. National Accelerometer Net renadic.cl, Report 10/08, University of Chile

BS 8006 (2010). Code of practice for strengthened/reinforced soil and other fills. British Standard Institution, Milton Keynes, UK

Buckle, I., Hube, M., Chen, G., Yen, W.H. and Arias, J. (2012). Structural performance of bridges in the offshore Maule earthquake of 27 February 2010. Earthquake Spectra 28(1), 533-552

Das, B.M. (2012). Retaining walls. Handbook of Geosynthetic Engineering. Geosynthetics and their applications. Edited by Shukla,
S.K. Second edition. Thomas Telford

FHWA (2011). Postearthquake reconnaissance report on transportation infrastructure impact of the February 27, 2010, offshore Maule Earthquake in Chile. Federal Highway Administration USA. Publication No. FHWA-HRT-11-030

FHWA (2009). Design and construction of mechanically stabilized earth walls and reinforced soil slopes. Federal Highway Administration USA. Publication No. FHWA-NHI-10-024

FHWA (2001). Mechanically stabilized earth walls and reinforced soil slopes design and construction guidelines. Federal Highway Administration USA. Publication No. FHWA-HRT-00-043

Galindo, A. (2014). Actualidad del diseño de muros de suelo reforzado, análisis comparativo entre FHWA NHI-10-024 (EEUU), BS8006 (Gran Bretaña) y EBGEO 2010 (Alemania). Ingeniería Civil $175,115-124$

Geo5 (2015). MSE wall. Verification of mechanically stabilized earth walls and segmental retaining walls reinforced by geogrids. Fine civil engineering software. Praha, Czech Republic

GGU Stability (2015). Slope stability analysis and analysis of soil nailing and reinforced earth walls. GGU GmbH, CivilServe

González, M.D. (2015). Design and construction of retaining structures reinforced by geogrids for bridge abutments. Civil Engineer degree project, Catholic University of Concepción, Chile (in Spanish)

Helwany, S.M., Wu, J.T. and Froessl, B. (2003). GRS bridge abutments - an effective means to alleviate bridge approach settlement. Geotextiles and Geomembranes 21(3), 177-196

Hube, M., Santa María, H. and Villalobos, F. (2010). Preliminary analysis of the seismic response of bridges during the Chilean 27 February 2010 earthquake. Obras y Proyectos 8, 48-57

Jacobs, F., Ruiken, A. and Ziegler, M. (2016). Investigation of kinematic behavior and earth pressure development of geogrid reinforced soil walls. Transportation Geotechnics 8, 57-68.

Koseki, J., Koda, M., Matsuo, S., Takasaki, H. and Fujiwara, T. (2012). Damage to railway earth structures and foundations caused by the 2011 off the Pacific Coast of Tohoku Earthquake. Soils and Foundations 52(5), 872-889

Ledezma, C., Hutchinson, T., Ashford, S.A., Moss, R., Arduino, P., Bray, J.D., Olson, S., Hashash, Y.M., Verdugo, R., Frost, D. and 
Kayen, R. (2012). Effects of ground failure on bridges, roads, and railroads. Earthquake Spectra 28(1), 119-143

Ruiz-Tagle, L. and Villalobos, F. (2011a). Experimental study of the lateral earth pressure on retaining structures in soils reinforced with geogrids. Revista Ingeniería de Construcción 26(3), 299-320

Ruiz-Tagle, L. and Villalobos, F. (2011b). Estudio experimental y numérico del desplazamiento y rotación de suelo reforzado con geomallas bajo empuje activo. Obras y Proyectos 9, 59-65

Soubra, A.H. (1999). Upper-bound solutions for bearing capacity of foundations. Journal of Geotechnical and Geoenviromental Engineering $\mathbf{1 2 5}$, No. 1, 59-68
Tatsuoka, F., Koseki, J., Tateyama, M., Munaf, Y. and Horii, K. (1998). Seismic stability against high seismic loads of geosyntheticreinforced soil retaining structures. $6^{\text {th }}$ International Conference on Geosynthetics, Atlanta, USA, R.K. Rowe ed., vol. 1, 103-142

Tatsuoka, F., Tateyama, M. and Koseki, J. (1996). Performance of soil retaining walls for railway embankments. Soils and Foundations 36, 311-324

Verdugo, R., Villalobos, F., Yasuda, S., Konagai, K., Sugano, T., Okamura, M., Tobita, T. and Torres, A. (2010). Description and analysis of geotechnical aspects associated to the large 2010 Chile earthquake. Obras y Proyectos 8, 25-36 